\title{
Near-shore distribution of alien Ponto-Caspian amphipods in a European dam reservoir in relation to substratum type and occurrence of macroinvertebrate taxa
}

\author{
Małgorzata Poznańska-Kakareko ${ }^{1, *}$, Milena Lis ${ }^{1}$, Tomasz Kakareko ${ }^{2}$, Mateusz Augustyniak ${ }^{2}$, \\ Piotr Kłosiński ${ }^{2}$ and Jarosław Kobak ${ }^{1}$ \\ ${ }^{1}$ Nicolaus Copernicus University, Faculty of Biological and Veterinary Sciences, Department of Invertebrate Zoology and Parasitology, \\ Lwowska 1, Toruń 87-100, Poland \\ ${ }^{2}$ Nicolaus Copernicus University, Faculty of Biological and Veterinary Sciences, Department of Ecology and Biogeography, Lwowska \\ 1 , Toruń $87-100$, Poland
}

Received: 17 September 2020 / Accepted: 27 January 2021

\begin{abstract}
Knowledge of habitat requirements and interspecific interactions of invasive species helps predict their impact and spread. We determined the relationships within the invasive freshwater Ponto-Caspian amphipod assemblage, and their associations with macroinvertebrates in the near-shore zone of a central European lowland dam reservoir. We sampled five habitat types: bare sand at the water line, bare sand ( $0.2 \mathrm{~m} \mathrm{depth})$, bare sand $(0.5 \mathrm{~m}$ depth), macrophyte-overgrown sand (1 m depth), stones $(0.3 \mathrm{~m}$ depth) on four dates (October 2015-October 2016). Pontogammarus robustoides occurred in all habitats, Dikerogammarus villosus and Echinogammarus ischnus were limited to the stony bottom. Amphipod densities were positively associated with one another except Dikerogammarus juveniles, negatively correlated with adults. The occurrence of $D$. villosus, juvenile Dikerogammarus and E. ischnus was positively related to the presence of the shelter-forming bivalve Dreissena polymorpha. Pontogammarus robustoides was positively associated with sphaeriid clams and gastropods (shelters), as well as oligochaetes and chironomids (potential prey items). Dikerogammarus villosus and E. ischnus were positively related to chironomids and oligochaetes, respectively. Coexistence of various alien amphipods in the studied area, indicated by prevailing positive relationships in their assemblage, may be enabled by the abundance of shelters and rich food sources allowing habitat partitioning.
\end{abstract}

Keywords: Invasive species / substratum selection / interspecies interactions / macrozoobenthos

Résumé - Répartition des amphipodes exotiques Ponto-Caspiens sur le littoral d'un réservoir de barrage européen en fonction du type de substrat et de la présence de taxons de macro-invertébrés. La connaissance des besoins en matière d'habitat et des interactions interspécifiques des espèces envahissantes permet de prévoir leur impact et leur propagation. Nous avons déterminé les relations au sein de l'assemblage d'amphipodes d'eau douce envahissants Ponto-Caspiens, et leurs associations avec les macroinvertébrés dans la zone proche du rivage d'un réservoir de barrage de plaine d'Europe centrale. Nous avons échantillonné cinq types d'habitats : le sable nu du rivage, le sable nu ( $0.2 \mathrm{~m}$ de profondeur), le sable nu $(0.5 \mathrm{~m}$ de profondeur), le sable recouvert de macrophytes $(1 \mathrm{~m}$ de profondeur), les pierres $(0.3 \mathrm{~m}$ de profondeur) à quatre dates (octobre 2015 à octobre 2016). Pontogammarus robustoides était présent dans tous les habitats, Dikerogammarus villosus et Echinogammarus ischnus étaient limités au fond rocheux. Les densités d'amphipodes étaient positivement associées les unes aux autres, à l'exception des juvéniles de Dikerogammarus, qui étaient négativement corrélées aux adultes. La présence de D. villosus, de Dikerogammarus juvéniles et $d^{\prime} E$. ischnus était positivement liée à la présence du bivalve formant abri Dreissena polymorpha. Pontogammarus robustoides a été positivement associé aux sphaeriidés et aux gastéropodes (abris), ainsi qu'aux oligochètes et aux chironomes (proies potentielles). Dikerogammarus villosus et $E$. ischnus ont été positivement associés aux chironomes et aux oligochètes, respectivement. La coexistence de divers amphipodes exotiques dans la zone étudiée, indiquée par les relations positives

\footnotetext{
*Corresponding author: mpoznan@umk.pl
} 
prédominantes dans leur assemblage, peut être rendue possible par l'abondance des abris et la richesse des sources de nourriture permettant le cloisonnement de l'habitat.

Mots clés : Espèces envahissantes / sélection du substrat / interactions entre espèces / macrozoobenthos

\section{Introduction}

Invasive organisms constitute a considerable threat to global biodiversity (Simberloff, 2000; Simberloff et al., 2013), freshwater habitats being one of the most susceptible to their impact (Dudgeon et al., 2006; Ricciardi and MacIsaac, 2010). To be able to efficiently monitor, control and predict the spread and impact of invaders, we need to determine their habitat requirements and interactions with other biota, both native and alien. This requires both experimental studies determining causal relationships among observed phenomena and field surveys depicting real-world situations taking place in the wild.

Several species of Ponto-Caspian amphipod crustaceans (gammarids and corophiids) established their populations in benthic communities of European inland waters in the 20th century (Bij de Vaate et al., 2002; Jażdżewski et al., 2002). In invaded ecosystems, they prey upon (MacNeil et al., 1997; Berezina and Panov, 2003; Devin et al., 2003) and compete (Piscart et al., 2011) with local benthic organisms, constitute a food source for fish (Grabowska and Grabowski, 2005; Kakareko et al., 2005) and contribute to organic matter decomposition (MacNeil et al., 2011). Therefore studies on factors affecting their distribution in the field are urgently needed.

Several Ponto-Caspian amphipods (Dikerogammarus villosus (Sowinski, 1894), Dikerogammarus haemobaphes (Eichwald, 1841), Echinogammarus ischnus (Stebbing, 1899), Chelicorophium curvispinum (G.O. Sars, 1895)) are associated with hard substrata, such as stones, coarse gravel and solid artificial objects (Muskó, 1993; Dermott et al., 1998; Devin et al., 2003; Van Overdijk et al., 2003; Kobak et al., 2015; Borza et al., 2017a). Other species, such as Pontogammarus robustoides (G.O. Sars, 1894), commonly occur on sandy bottoms (Gruszka, 1999; Jażdżewski et al., 2002; Żytkowicz et al., 2008). Macrophytes and colonies of the Ponto-Caspian zebra mussel (Dreissena polymorpha (Pallas, 1771)) also create living places for amphipods, increasing habitat complexity, offering anti-predation protection and food (Gosselin and Chia, 1995; Stewart et al., 1998a; González and Burkart, 2004; Rewicz et al., 2014), as well as attachment sites for corophiids (Van den Brink et al., 1993; Lucy et al., 2004). Food resources for omnivorous gammarids include detritus (Baceela-Spychalska and Van der Velde, 2013; Richter et al., 2018), macroinvertebrates (mainly chironomid larvae and oligochaetes) (Bącela-Spychalska and Van der Velde, 2013; Rewicz et al., 2014), periphyton covering hard surfaces and macrophytes (Berezina, 2007b), as well as mussel faeces and pseudofaeces (Karatayev et al., 2002; González and Burkart, 2004). The proportion of macroinvertebrates increases in the diet of adult and large gammarids (Berezina, 2007a).

Interspecific interactions among amphipods can be quite complicated: they can live together in diverse habitats (Piscart et al., 2010; Borza et al., 2017b), allowing spatial segregation of species (Kley and Maier, 2005; Żytkowicz et al., 2008). Alternatively, a stronger competitor can displace weaker ones to other habitats (Kley and Maier, 2003; Grabowski et al., 2007; Kobak et al., 2016). Intra-guild predation (Dick et al., 1999; MacNeil, 2019) and cannibalism of adults preying upon juveniles (MacNeil et al., 1999) may also affect the amphipod distribution (Devin et al., 2003; Jermacz et al., 2015a; Kobak et al., 2015).

Selected relationships of the Ponto-Caspian amphipods with the above-mentioned environmental variables have already been examined in experimental studies (Platvoet et al., 2009; Van Riel et al., 2009; Bącela-Spychalska and Van Der Velde, 2013; Jermacz et al., 2015a; Kobak et al., 2015; MacNeil, 2019). Nevertheless, it is not always clear how these factors interact with one another in the wild to shape the actual distribution of alien species. For example, some authors highlight the positive effect of $D$. polymorpha beds on Dikerogammarus spp. (Devin et al., 2003; Kobak and Żytkowicz, 2007; Kobak et al., 2009; Boets et al., 2010), while laboratory studies found the opposite (Gergs and Rothhaupt, 2008; Kobak et al., 2015). Similarly, laboratory experiments show that amphipods include Chironomidae and Oligochaeta in their diet (Bącela-Spychalska and Van der Velde, 2013; Richter et al., 2018), but conflicting evidence also exists (Koester et al., 2016), and it is not known whether amphipods are spatially associated with these taxa in the field.

We intended to check whether and to what extent the relationships found in earlier laboratory experiments (Kley et al., 2009; Platvoet et al., 2009; Van Riel et al., 2009; Boets et al., 2010; Czarnecka et al., 2010; Jermacz et al., 2015a, 2015b; Kobak et al., 2015, 2016, 2017; MacNeil, 2019) occur in real field conditions. We tested relationships of invasive Ponto-Caspian amphipod taxa with one another, as well as between them and other macroinvertebrates, in diverse habitats of a dam reservoir on a large European river. Such relationships have not been commonly tested so far, especially for the species used in our study and in anthropogenic water bodies, often constituting alien species hot spots (Bij de Vaate et al., 2002; Żytkowicz et al., 2008). We hypothesized that: (1) Amphipods associated with hard surfaces (D. villosus, D. haemobaphes, E. ischnus, Ch. curvispinum) would be positively associated with $D$. polymorpha colonies (Devin et al., 2003; Van Overdijk et al., 2003; González and Burkart, 2004; Kobak and Żytkowicz, 2007) and other hard-shelled molluscs, particularly at locations without $D$. polymorpha. (2) Pontogammarus robustoides would be less selective with regard to substratum type, inhabiting diverse habitats (Żytkowicz et al., 2008; Czarnecka et al., 2009; Jermacz et al., 2015a). (3) Adult D. villosus, being the strongest competitor in the assemblage (Kley and Maier, 2003; Van Riel et al., 2006), would be negatively related to the density of other amphipods and smaller conspecifics (Dick and Platvoet, 2000; Rewicz et al., 2014; Jermacz et al., 2015b; Kobak et al., 2016). (4) The density of amphipods may be positively correlated with that of Chironomidae larvae and Oligochaeta if these organisms constitute suitable food sources for them (BacelaSpychalska and Van der Velde, 2013). Some laboratory studies 


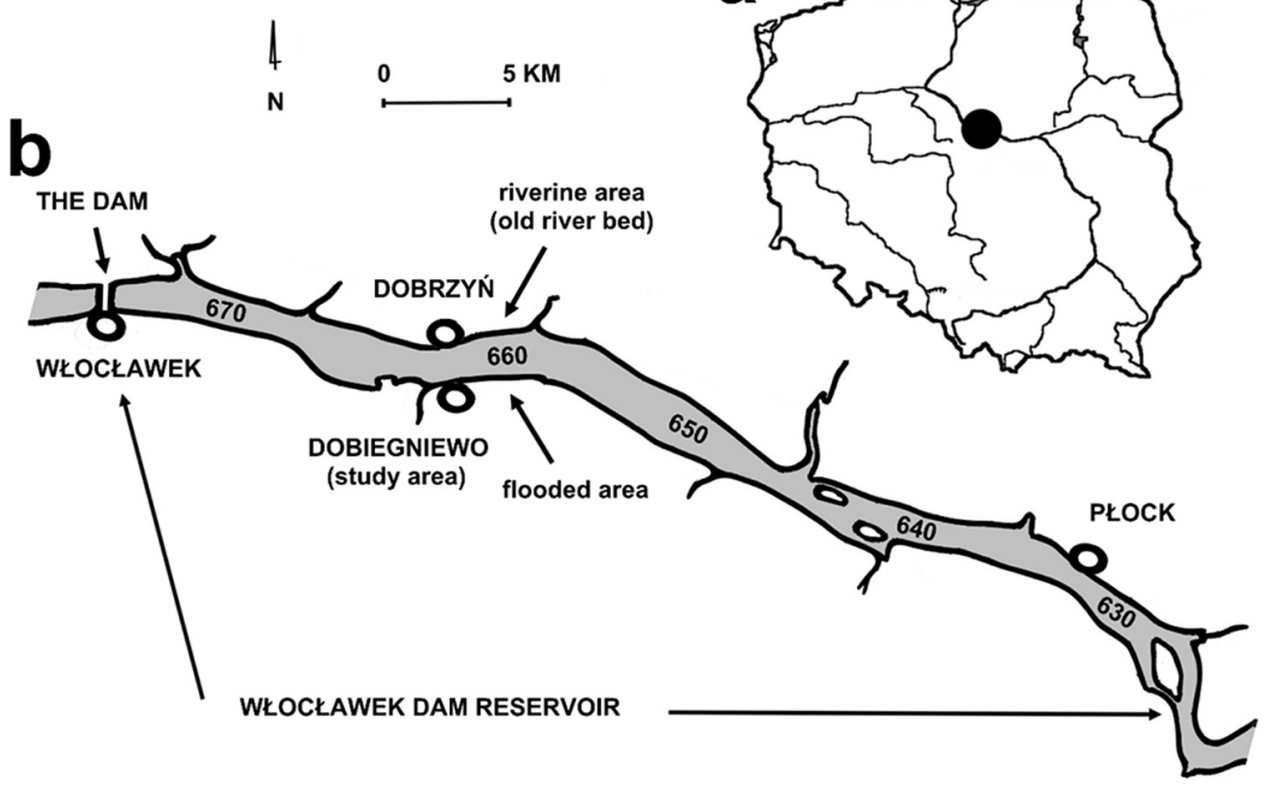

Fig. 1. Study area. (a) Location of the Włocławek Dam Reservoir in Poland. (b) Study sites.

suggest that omnivorous amphipods may be attracted to chironomids (Gergs and Rothhaupt, 2008), though others do not confirm such observations (Czarnecka et al., 2010). Alternatively, as the growing body of evidence shows that Ponto-Caspian amphipods are more herbivorous than previously believed (Koester et al., 2016, 2018), the densities of these taxa may be independent of one another.

\section{Methods}

\subsection{Study area and sample collection}

The Włocławek Dam Reservoir (Fig. 1a) was created in 1970 on the lower Vistula River (Poland). This is a large (area: $75 \mathrm{~km}^{2}$; capacity: 400 million $\mathrm{m}^{3}$ ), shallow (average depth: $5.5 \mathrm{~m}$; maximum depth: $15 \mathrm{~m}$ ) and eutrophic reservoir with a high length: width ratio, regular shape and very short retention time (4-5 days) (Giziński et al., 1989). During the study, the maximum amplitude of the water level was $67 \mathrm{~cm}$ (data from the Polish Water Management "Polish Waters", Regional Water Management Board in Warsaw, Suppl. material 1). The bottom fauna (including sensitive species) are able to survive long periods of air exposure (LT50 over 8 days at a water content of $7.1 \%$ ) provided that the substratum is humid (Poznańska-Kakareko et al., 2017). That 8-day threshold was exceeded only once during our study period (10 days in January 2016), but the fauna had enough time for recovery (Leigh et al., 2016; Vander Vorste et al., 2016) before our next sampling.

We collected samples along the left bank of the middle part of the reservoir $\left(52^{\circ} 37^{\prime} 03^{\prime \prime} \mathrm{N} 19^{\circ} 19^{\prime} 37^{\prime \prime} \mathrm{E}\right)$ in a flooded area (Fig. 1b) with a gentle bottom slope. We took samples from five types of typical near shore bottom habitats in the area: (1) bare sand at the water line; (2) bare sand at a depth of $0.2 \mathrm{~m}$; (3) bare sand at a depth of $0.5 \mathrm{~m}$; (4) sandy bottom overgrown by macrophytes; (5) stony substratum (Tab. 1). We collected samples on four dates: 14 October 2015; 2 April 2016; 5 July
2016; 18 October 2016. On each date, we sampled three sites randomly selected in each habitat type, at least $5 \mathrm{~m}$ apart (12 separate samples from each habitat altogether). On each date, we established the positions of sampling sites in the two shallowest habitat types (1-2) to keep a constant depth depending on the fluctuating position of the water line. We defined the positions of sampling sites in the other habitat types (3-5) by the presence of specific habitat features. Due to the differences in bottom types among the habitats as well as in size, abundance and mobility among various taxa, we used three different sampling methods (Tab. 1). At the sandy bottom, we collected sediment-dwelling macroinvertebrates (except amphipods) using a core sampler with a catching area of $22 \mathrm{~cm}^{2}$, penetrating sediments to a depth of $29 \mathrm{~cm}$ (3 subsamples per sample). We sieved the collected sediments through a $0.5 \mathrm{~mm}$ sieve. We collected amphipods from the sandy bottom (quantitatively (Everall et al., 2017; Tubić et al., 2017)) using a 30-cm wide Surber net (1 mm sieve). One sample included sediments collected by dragging the net $30 \mathrm{~cm}$ along the bottom to sweep the surface layer of sediments, which resulted in a catching area of $900 \mathrm{~cm}^{2}$. One sample from the stone habitat was a single irregular piece of concrete (mean diameter: $14 \mathrm{~cm}, \mathrm{SD}=5.2$ ). We carefully removed stones from the water and gently scraped and rinsed out all organisms (including amphipods) onto the sieve from their upper surface. As the stones were buried in sand, only their upper surface was available to settling fauna. All these methods allowed us to take quantitative samples, that is, to collect all macroinvertebrate individuals from a given bottom area, thus their results can be considered as comparable among habitats for each taxon. We preserved the fauna in $4 \%$ formaldehyde. We estimated the projected areas of photographed top stone surfaces available for the fauna using ImageJ software (http:// rsb.info.nih.gov/ij). We calculated densities of all organisms per $1 \mathrm{~m}^{2}$. In the laboratory, we identified the fauna to species or genus (as far as possible) according to Piechocki and Wawrzyniak-Wydrowska (2016) for Mollusca, 
Wiederholm (1983) for Chironomidae larvae, Kasprzak (1981) and Timm (2009) for Oligochaeta, Konopacka (2004) for Amphipoda. Trichoptera, Ceratopogonidae and Nematoda (only single specimens found) were not identified to a lower taxonomic level.

\subsection{Statistical analysis}

Due to the highly right-skewed distributions of amphipod densities (skewness ranging from 2.6 to 5.0), to compare amphipod densities among various substrata and seasons, we conducted 2-way Generalized Linear Models (GLM) (gamma distribution, log link function) with sampling date and habitat type as factors. Dependent variables in these analyses were densities (with each data point modified as $\mathrm{X}+1$ to avoid zero values, not handled by the gamma distribution) of identified amphipod taxa: P. robustoides, E. ischnus and D. villosus, as well as juvenile Dikerogammarus spp. (where the species identity was impossible to determine). Nevertheless, due to the very low occurrence of $D$. haemobaphes adults (just 2 individuals in the entire study, see Results section), it is likely that most of the juvenile Dikerogammarus spp. were in fact $D$. villosus. Due to the low occurrence of $D$. haemobaphes, as well as of Ch. curvispinum, we excluded them from the analysis. We further analysed significant effects in the models with pairwise contrasts as post-hoc tests.

To check the relationships between particular amphipod taxa and other organisms, as well as their habitat associations, we conducted a Correspondence Analysis (CA) with logtransformed densities of the most common groups of macrozoobenthos (i.e. Chironomidae, Oligochaeta, Gastropoda, D. polymorpha, Sphaeriidae) and amphipods: P. robustoides, E. ischnus and D. villosus, as well as juvenile Dikerogammarus spp. For macrozoobenthos, we combined lower taxonomic units (species and genera) to reduce the number of variables. We assumed that omnivorous amphipods would be unlikely to discriminate between particular species as potential food sources. As in the first run of this analysis the stony habitat appeared to distinctly depart from the others, we conducted a second CA, excluding samples collected from stones, to further evaluate more subtle relationships in the remaining habitats, potentially obscured by the strong distinctness of the stony habitat.

We analysed relationships among amphipods and other organisms using GLMs (gamma distribution with log-link function due to the highly right-skewed distribution of the data) with the density of a particular amphipod group (modified as $\mathrm{X}+1$, see above) as a response variable, sampling date as a categorical factor (to control for its effect), and densities of the above mentioned groups of macrozoobenthos and other amphipods as continuous covariates. We conducted separate GLMs for each habitat type (in which a given amphipod group occurred), using sets of taxa occurring in particular habitats. This approach allowed us to check for interspecific relationships independent of their potential preferences for or avoidances of specific habitat types (i.e. within each habitat). Assuming that juveniles are unlikely to affect adults, we did not use their densities as explanatory variables in the analyses of adult individuals, only the other way round.

GLMs were conducted with SPSS 26.0 (IBM inc.) and CAs with Vegan 2.5-3 package for R (Oksanen et al., 2018). 

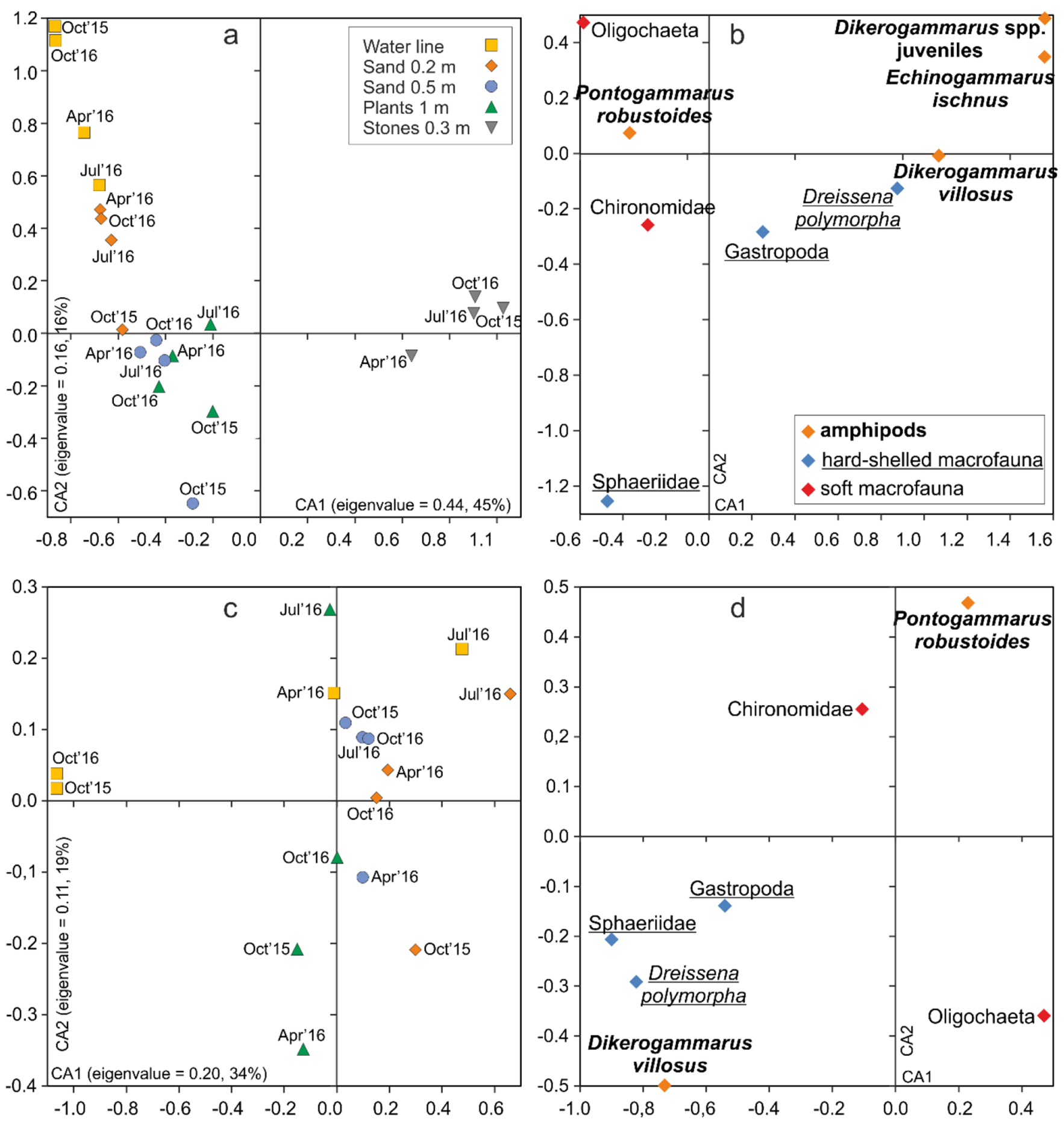

Fig. 2. Correspondence analysis ordination of macroinvertebrate taxa (including amphipods) and sites belonging to different habitat types. The analysis was based on samples from all the habitats ( $a$ and b) or excluding stone sites (c and d).

\section{Results}

\subsection{Macroinvertebrate distribution (including amphipods) in particular habitats}

The highest total macroinvertebrate density, averaged across all the sampling dates (20 247 ind $\mathrm{m}^{-2}$ ) was found on the stony bottom (Suppl. material 2) whereas the lowest density was found at the water line (461 ind $\mathrm{m}^{-2}$ ) (Suppl. material 2).

The Correspondence Analysis (Fig. 2) showed a high differentiation of the stony habitat from the remaining samples along the first CA axis (Fig. 2a). The stones were mainly occupied by $D$. villosus, juvenile Dikerogammarus spp., E. ischnus, D. polymorpha (12000 ind $\mathrm{m}^{-2}$, over $60 \%$ of the total macroinvertebrate density in this habitat, Suppl. material 2) 
and gastropods (Fig. 2b). The soft bottom samples were dominated by $P$. robustoides, chironomids, oligochaetes and sphaeriid clams.

The second CA axis discriminated the shallower sandy sites from deeper locations (Figs. 2a and 2b). The water line habitat was inhabited only by Oligochaeta $(89 \%$ of the total density) and Amphipoda (P. robustoides) (10\%) (Suppl. material 2). The sandy bottom at a depth of $0.2 \mathrm{~m}$ was inhabited by Chironomidae larvae (43\%), Oligochaeta (34\%) and Amphipoda ( $P$. robustoides) (23\%). The greatest density and richness of chironomids, Oligochaeta and Bivalvia (except D. polymorpha, reaching the highest density on stones) was found on the deeper sandy bottom (depth of 0.5 and $1 \mathrm{~m}$ with macrophytes) (Suppl. material 2).

The CA analysis carried out on sandy substrata only (Figs. 2c and 2d) revealed associations between D. villosus and hard-shelled taxa (D. polymorpha, gastropods and sphaeriids), as well as between $P$. robustoides and Chironomidae, Oligochaeta.

\subsection{Amphipod distribution in particular habitats and seasons}

Pontogammarus robustoides was present in all habitats and on all dates (Fig. 3a; Suppl. material 2), though at different densities, as shown by a significant habitat type $\times$ sampling date interaction (Tab. 2a). Significant differences in its density among habitats occurred on both autumn dates (Fig. 3a; Suppl. material 3a). Its density was lower at the water line than elsewhere and, in October'16, higher on stones than in the other habitats (Fig. 3a; Suppl. material 2, 3a).

The density of D. villosus (Fig. 3b; Suppl. material 2) depended on a significant interaction between habitat type and sampling date (Tab. 2b). On all the dates, its density was higher on the stony bottom than among macrophytes (Fig. 3b; Suppl. material 3a), whereas it was absent from the other habitats. Its density in October' 15 was higher than on the other dates (Fig. 3b; Suppl. material 3b).

Dikerogammarus juveniles, E. ischnus, D. haemobaphes and Ch. curvispinum occurred almost exclusively on the stony bottom (Fig. 3b; Suppl. material 2). This resulted in a

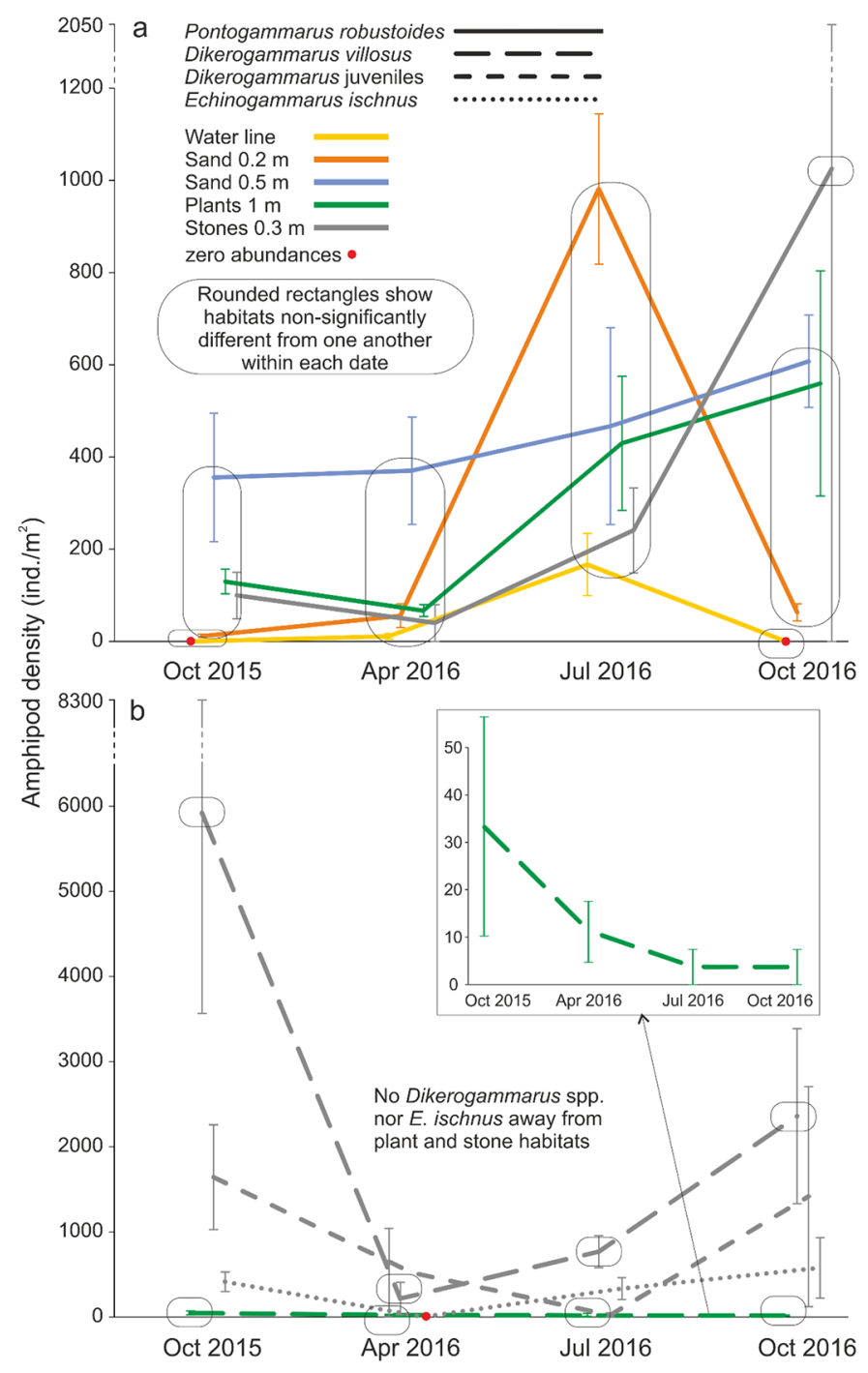

Fig. 3. Mean densities ( \pm SE) of amphipod species/groups in various habitats on particular dates. (a) Density (ind $\mathrm{m}^{-2}$ ) of Pontogammarus robustoides (b) Density (ind $\mathrm{m}^{-2}$ ) of Dikerogammarus villosus, Dikerogammarus spp. juv. and Echinogammarus ischnus.

Table 2. Two-way Generalized Linear Models (Gamma distribution, log link function) to test the effect of sampling date and habitat type on the density of amphipods.

\begin{tabular}{|c|c|c|c|c|}
\hline Species/group & Effect & df & $x^{2}$ & $P$ \\
\hline \multirow{3}{*}{ (a) Pontogammarus robustoides } & Sampling date (D) & 3 & 327.2 & $<0.001^{*}$ \\
\hline & Habitat type $(\mathrm{H})$ & 4 & 67.9 & $<0.001^{*}$ \\
\hline & $\mathrm{D} \times \mathrm{H}$ & 12 & 929.8 & $<0.001^{*}$ \\
\hline \multirow{3}{*}{ (b) Dikerogammarus villosus } & Sampling date (D) & 3 & 13.8 & $0.003^{*}$ \\
\hline & Habitat type $(\mathrm{H})$ & 4 & 894.4 & $<0.001^{*}$ \\
\hline & $\mathrm{D} \times \mathrm{H}$ & 12 & 37.9 & $<0.001^{*}$ \\
\hline \multirow{3}{*}{ (c) Dikerogammarus juveniles } & Sampling date (D) & 3 & 4.5 & 0.215 \\
\hline & Habitat type $(\mathrm{H})$ & 4 & 178.3 & $0.001^{*}$ \\
\hline & $\mathrm{D} \times \mathrm{H}$ & 12 & 17.9 & 0.119 \\
\hline \multirow{3}{*}{ (d) Echinogammarus ischnus } & Sampling date (D) & 3 & 79.5 & $<0.001^{*}$ \\
\hline & Habitat type $(\mathrm{H})$ & 4 & 948.3 & $<0.001^{*}$ \\
\hline & $\mathrm{D} \times \mathrm{H}$ & 12 & 317.8 & $<0.001^{*}$ \\
\hline
\end{tabular}

*Asterisks indicate statistically significant effects. 
significant habitat type effect for Dikerogammarus juveniles (Tab. 2c). E. ischnus was absent in April'16, which caused a significant habitat type $\times$ sampling date interaction (Tab. 2d). D. haemobaphes and Ch. curvispinum were not formally analysed due to their very low density.

\subsection{Relationships between amphipods and macroinvertebrate taxa}

The density of $P$. robustoides was positively related to the occurrence of hard-shelled taxa: sphaeriid clams among macrophytes and Gastropoda on stones (Tab. 3a; Suppl. material 4). It was also positively associated with the presence of chironomids (macrophytes and stones) and oligochaetes (macrophytes). On the other hand, P. robustoides was negatively associated with $D$. polymorpha on plants (Tab. 3a; Suppl. material 4). Moreover, its density was positively associated with the occurrence of other amphipods: $D$. villosus and E. ischnus on stones (Tab. 3a; Suppl. material 4).

The occurrence of $D$. villosus was positively correlated to the presence of D. polymorpha and Chironomidae and negatively associated with oligochaetes on stones (Tab. 3b; Suppl. material 4). Moreover, it was positively related to the occurrence of other amphipods: E. ischnus and P. robustoides (Tab. 3b; Suppl. material 4). The occurrence of Dikerogammarus juveniles was positively associated with $D$. polymorpha and $E$. ischnus and negatively related to adult D. villosus (Tab. 3c; Suppl. material 4). The density of E. ischnus was positively related to that of $D$. polymorpha, Oligochaeta, $D$. villosus and P. robustoides and negatively associated with Gastropoda (Tab. 3d; Suppl. material 4).

\section{Discussion}

\subsection{Associations of amphipods with hard substrata (stones, molluscs)}

All the amphipods studied except $P$. robustoides were strongly associated with stony substrata. This confirms earlier experimental and field observations on D. villosus (Van Riel et al., 2009; Kobak et al., 2015; Borza et al., 2017a), D. haemobaphes (Muskó, 1993; Wawrzyniak-Wydrowska and Gruszka, 2005; Muskó et al., 2007) and E. ischnus (Dermott et al., 1998). It should be noted that all stones in our study area were fouled by the zebra mussel, definitely modifying the conditions for the bottom fauna. Thus, amphipods in our study had no other option for the hard substratum but to have some contact with mussel colonies, as all the available stones were overgrown by mussels to a variable extent. However, we found positive relationships between these taxa in the analyses conducted separately for each habitat type, that is, irrespective of animal preferences for particular habitats. Thus, amphipod densities were higher on stones more densely overgrown by mussels. This habitat forming bivalve provides benthic organisms with shelters and food sources (Karatayev et al., 1997), but also reduces oxygen resources (Effler et al., 1996) and increases the amount of waste products (Gergs and Rothhaupt, 2008). The positive relationship between amphipods and mussels in our study confirms laboratory and field observations of $D$. villosus (Devin et al., 2003; Boets et al.,
2010), D. haemobaphes (Kobak and Żytkowicz, 2007; Kobak et al., 2009) and E. ischnus (Stewart et al., 1998b; Van Overdijk et al., 2003; González and Burkart, 2004). Several non-amphipod taxa also increase their densities and/or exhibit preferences for mussel colonies, including mayflies (DeVanna et al., 2011), gastropods (Stewart et al., 1999), chironomids (Wolnomiejski, 1970) and turbellarians (Stewart et al., 1998a; 1998b). Nevertheless, laboratory experiments have shown a more complex picture of amphipod-mussel interactions, indicating the lack of preferences or even active avoidance of mussels by D. villosus (Gergs and Rothhaupt, 2008; Kobak et al., 2015). This was attributed to the increased ammonium content and/or reduced oxygen concentration in a colony (Gergs and Rothhaupt, 2008; Kobak et al., 2015). Our results show that the benefits of living in a mussel colony prevailed over disadvantages in the field. Probably, attributes of the dam reservoir, such as good oxygenation (Poznańska et al., 2009, 2010) and fast water exchange (Giziński et al., 1989) reduced negative effects of a mussel bed. This suggests that amphipods can make fine adjustments of their habitat selection depending on multiple environmental factors and select zebra mussel colonies only when the local environmental conditions permit.

On the other hand, $P$. robustoides was not related to D. polymorpha aggregations on stones and even negatively associated with this mollusc among macrophytes, confirming earlier laboratory observations (Kobak and Żytkowicz, 2007). However, we observed positive associations of $P$. robustoides with other hard-shelled taxa: gastropods (on stones) and sphaeriid clams (among macrophytes). The multivariate analysis suggested that $D$. villosus was also positively associated with other hard-shelled taxa on the soft bottom (Fig. 2d), where D. polymorpha was less common. This emphasizes the affinity of the studied amphipods to organisms increasing substratum complexity and providing solid objects (potential shelters) on the soft bottom.

\subsection{Associations of amphipods with soft substrata (sand, macrophytes)}

Juvenile D. villosus (Devin et al., 2003; Kobak et al., 2015) and adult E. ischnus (González and Burkart, 2004; Żytkowicz et al., 2008) have previously been observed on macrophytes, but in our study they were either absent or rare in this habitat. Perhaps, $P$. robustoides was capable of outcompeting other taxa on these substrata, in contrast to the stony habitat, where numerous shelters allowed all the species to co-occur. Pontogammarus robustoides successfully defended shelters against $D$. villosus when it was introduced earlier to the environment (Kobak et al., 2016), supporting this speculation. Nevertheless, the effect of various substratum types on the outcome of interference interactions between amphipod taxa is still to be checked in future experimental studies.

Pontogammarus robustoides is the least selective with regard to the substrata (Kobak and Żytkowicz, 2007; Żytkowicz et al., 2008) and the most explorative of PontoCaspian amphipods (Kobak et al., 2016). Accordingly, in our study, it was the only species reaching high densities in sandy habitats. This is consistent with earlier field observations of its occurrence in shallow sandy areas (Gruszka, 1999; Jażdżewski et al., 2002; Żytkowicz et al., 2008). The affinity of 
M. Poznańska-Kakareko et al.: Knowl. Manag. Aquat. Ecosyst. 2021, 422, 5

Table 3. Generalized Linear Models (Gamma distribution, log link function) to test the relationships among particular amphipod groups and other macroinvertebrate taxa.

\begin{tabular}{|c|c|c|c|c|c|}
\hline Amphipod & Habitat & Covariate & $\chi^{2}$ & $P$ & $B$ \\
\hline \multirow{18}{*}{ (a) Pontogammarus robustoides } & \multirow{2}{*}{ Sand $0.2 \mathrm{~m}$} & Chir & 3.1 & 0.079 & \\
\hline & & Oli & 0.4 & 0.534 & \\
\hline & \multirow{5}{*}{ Sand $0.5 \mathrm{~m}$} & Gastr & 1.4 & 0.229 & \\
\hline & & $\mathrm{Dp}$ & 0.5 & 0.479 & \\
\hline & & Sph & 0.0 & 0.877 & \\
\hline & & Chir & 0.6 & 0.422 & \\
\hline & & Oli & 0.0 & 0.878 & \\
\hline & \multirow{6}{*}{ Plants } & Dv & 2.0 & 0.156 & \\
\hline & & Gastr & 0.1 & 0.714 & \\
\hline & & $\mathrm{Dp}$ & 5.9 & 0.015 & -0.001 \\
\hline & & Sph & 62.2 & $<0.001$ & 0.003 \\
\hline & & Chir & 40.4 & $<0.001$ & 0.0001 \\
\hline & & Oli & 9.7 & 0.002 & 0.0001 \\
\hline & \multirow{6}{*}{ Stones } & Dv & 4.2 & 0.040 & 0.001 \\
\hline & & $\mathrm{Ei}$ & 9.6 & 0.002 & 0.005 \\
\hline & & Gastr & 6.3 & 0.012 & 0.00002 \\
\hline & & $\mathrm{Dp}$ & 2.9 & 0.089 & \\
\hline & & Chir & 57.2 & $<0.001$ & 0.002 \\
\hline \multirow{13}{*}{ (b) Dikerogammarus villosus } & & Oli & 0.1 & 0.796 & \\
\hline & \multirow{6}{*}{ Plants } & $\operatorname{Pr}$ & 0.7 & 0.401 & \\
\hline & & Gastr & 2.3 & 0.134 & \\
\hline & & $\mathrm{Dp}$ & 0.7 & 0.392 & \\
\hline & & $\mathrm{Sph}$ & 1.0 & 0.327 & \\
\hline & & Chir & 1.0 & 0.311 & \\
\hline & & Oli & 0.6 & 0.425 & \\
\hline & \multirow{6}{*}{ Stones } & $\operatorname{Pr}$ & 16.0 & $<0.001$ & 0.002 \\
\hline & & $\mathrm{Ei}$ & 3.7 & 0.043 & 0.002 \\
\hline & & Gastr & 0.2 & 0.686 & \\
\hline & & $\mathrm{Dp}$ & 93.6 & $<0.001$ & 0.0003 \\
\hline & & Chir & 20.0 & $<0.001$ & 0.001 \\
\hline & & Oli & 15.8 & $<0.001$ & -0.004 \\
\hline \multirow{7}{*}{ (c) Dikerogammarus juveniles } & \multirow{7}{*}{ Stones } & $\operatorname{Pr}$ & 0.6 & 0.427 & \\
\hline & & Dv & 11.1 & 0.001 & -1.95 \\
\hline & & $\mathrm{Ei}$ & 9.0 & 0.003 & 3.23 \\
\hline & & Gastr & 2.7 & 0.099 & \\
\hline & & $\mathrm{Dp}$ & 7.1 & 0.008 & 0.6 \\
\hline & & Chir & 2.2 & 0.143 & \\
\hline & & Oli & 1.6 & 0.203 & \\
\hline \multirow{6}{*}{ (d) Echinogammarus ischnus } & \multirow{6}{*}{ Stones } & $\operatorname{Pr}$ & 6.6 & 0.010 & 0.003 \\
\hline & & Dv & 7.9 & 0.005 & 0.003 \\
\hline & & Gastr & 5.7 & 0.017 & -0.0005 \\
\hline & & $\mathrm{Dp}$ & 6.4 & 0.012 & 0.001 \\
\hline & & Chir & 1.9 & 0.165 & \\
\hline & & Oli & 7.1 & 0.008 & 0.031 \\
\hline
\end{tabular}

Competitors/predators: Pr, Pontogammarus robustoides; Dv, Dikerogammarus villosus; Djuv, Dikerogammarus juveniles; Ei, Echinogammarus ischnus. Shelter providers: Gastr, Gastropoda; Dp, Dreissena polymorpha; Sph, Sphaeriidae; Chir, Chironomidae; Oli, Oligochaeta.

The models were conducted separately for each habitat type and included one of the amphipod groups as a response variable, sampling date (not shown) as a categorical factor and all other taxa present in a given habitat as covariates. Positive and negative values of regression parameters (B) shown for significant effects indicate positive and negative relationships (respectively).

P. robustoides to sandy habitats is aided by its adaptations to burrow in sediments (Poznańska et al., 2013). In earlier field studies, it also reached high densities on macrophytes (Żytkowicz et al., 2008; Czarnecka et al., 2009). On the other hand, it preferred large-grained substrata (coarse gravel) in the laboratory (Jermacz et al., 2015a), which may explain its occurrence and occasional high density on stones in our study. 


\subsection{Relationships within the amphipod assemblage}

Amphipod taxa were mostly positively associated with one another within particular habitats. D. villosus was found as an effective intra-guild predator exterminating other amphipods, both native and alien (Dick and Platvoet, 2000; Krisp and Maier, 2005). Nevertheless, the opposite evidence exists, showing that the impact of $D$. villosus on amphipods is limited (Piscart et al., 2010; Koester and Gergs, 2014). Our results seem to support the latter observation due to the limited number of negative relationships of $D$. villosus with other amphipods. Nevertheless, the drastic reduction in the density of $D$. haemobaphes, previously dominating in the studied area (Żytkowicz et al., 2008), coincided with the arrival of D. villosus (ca. 2009, personal observation). Replacements between these two species were also observed at other locations (Kley and Maier, 2003).

Nevertheless, D. villosus had no negative effect on E. ischnus. They were able to share a common living space, being positively correlated with each other. Earlier, E. ischnus had been limited to offshore locations of the studied area (Żytkowicz and Kobak, 2008), whereas now has spread to near-shore sites. Similarly, Hellmann et al. (2017) and Koester et al. (2018) found positive correlations between D. villosus and E. ischnus. This phenomenon could be attributed to habitat complexity (MacNeil et al., 2008; Piscart et al., 2010) or variability of flow conditions (Borza et al., 2017b) allowing spatial segregation. Perhaps, small E. ischnus utilizes smaller interstices among substratum particles, inaccessible for larger species (Borza et al., 2018). Besides, the presence of D. villosus might reduce the pressure of other species on E. ischnus, allowing it to expand its occurrence. Such nonconsumptive negative effects of $D$. villosus on large amphipods (increased mobility, migration and displacement) were observed by Van Riel et al. (2007), Jermacz et al. (2015b) and Kobak et al. (2016).

We observed positive relationships between amphipod species previously found as negatively associated: $P$. robustoides vs. D. villosus (Jermacz et al., 2015b; Kobak et al., 2016) and P. robustoides vs. E. ischnus (Żytkowicz and Kobak, 2008). The coexistence between D. villosus and $P$. robustoides may be facilitated by the presence of a top predator (fish) inhibiting their agonistic interactions (Jermacz et al., 2015b). Benthivorous fish are common in the study area (Kakareko and Żbikowski, 2006), supporting this hypothesis. Another factor facilitating the amphipod coexistence in our study could be high food availability: high density of macroinvertebrates (Poznańska et al., 2009, 2010), rich periphyton and detritus in mussel beds. This can reduce the predatory pressure of larger amphipods on their smaller relatives.

The only negative interaction within the amphipod assemblage in our study took place between $D$. villosus and Dikerogammarus juveniles. The latter (probably mostly D. villosus) were previously found to avoid adults in the field (Devin et al., 2003) and laboratory (Kobak et al., 2015). Although, in contrast to the findings by Devin et al. (2003), juveniles did not switch to other substrata, we observed a separation within the stony habitat. This mechanism is likely to help them avoid cannibalism of adults and limit intraspecific competition.
The high number of positive associations within the amphipod assemblage in our study may contribute to the local invasional meltdown effect (Simberloff and Von Holle, 1999). However, the confirmation of this phenomenon needs further studies involving other parts of the local invasive community.

\subsection{Associations of amphipods with chironomids and oligochaetes}

Adult amphipods were generally positively associated with chironomids and oligochaetes in macrophytes and stony habitats (Suppl. material 4). This might follow from preferences of both groups for the same habitats, or preferences of amphipods for other organisms as suitable food sources. The associations were observed separately for each habitat type, which partly excludes the former mechanism. Nevertheless, it is still possible that animals selected particular patches within each habitat (i.e. specific stones or plant patches). Ponto-Caspian gammarids were observed to prefer food of animal origin (Dick et al., 2002; Krisp and Maier, 2005; Gergs and Rothhaupt, 2008; Maier et al., 2011; Bącela-Spychalska and Van der Velde, 2013), suggesting the latter mechanism, although opposite evidence, pointing to the herbivorous nature of alien gammarids, also exists (Koester et al., 2016, 2018). Nevertheless, they seem to be able to intake animal food at least under specific conditions. Furthermore, non-predatory Dikerogammarus juveniles were not associated with chironomids and oligochaetes in our study. It should be noted that relationships between adult amphipods and chironomids and oligochaetes occurred in structured habitats (plants, stones), where mobility is likely to be reduced due to the abundance of shelters, increasing the affinity to food-rich locations.

\subsection{Summary}

In a eutrophic, riverine, lowland dam reservoir, we observed multiple positive links existing within the studied amphipod assemblage as well as between its members and other benthic organisms. Thus, we demonstrated that in the presence of diversified, well sheltered habitats and abundant food resources, negative relationships among amphipods may be reduced, enabling the existence of a rich multispecies assemblage.

\section{Conflict of interest}

All authors declare that no conflict of interest exists.

\section{Supplementary Material}

\section{Supplementary Material 1-4.}

The Supplementary Material is available at https://www.kmaejournal.org/10.1051/kmae/2021005/olm.

Acknowledgements. This research was supported by the Polish National Science Centre (NSC Grant No. 2012/05/B/NZ8/ 00479). We would like to thank Łukasz Jermacz and Anna Dzierżyńska- Białończyk for their help in sample collection as 
well as students from the Hydrobiological Unit of the Student Scientific Circle of Biologists for their help in sorting organisms. We are also grateful to the Polish Water Management "Polish Waters", Regional Water Management Board in Warsaw, Poland, for providing the data of water level fluctuations in the Włocławek Reservoir. We are deeply grateful to Mrs Hazel Pearson for improving the English language of our text. Finally, the authors thank the three anonymous reviewers for valuable comments and language corrections that helped us improve the text.

\section{References}

Bącela-Spychalska K, Van der Velde G. 2013. There is more than one "killer shrimp": Trophic positions and predatory abilities of invasive amphipods of Ponto-Caspian origin. Freshw Biol 58: 730-741.

Berezina N. 2007a. Food spectra and consumption rates of four amphipod species from the North-West of Russia. Fundam Appl Limnol/Arch fur Hydrobiol 168: 317-326.

Berezina N. 2007b. Invasions of alien amphipods (Amphipoda: Gammaridea) in aquatic ecosystems of North-Western Russia: pathways and consequences. Hydrobiologia 590: 15-29.

Berezina N, Panov VE. 2003. Establishment of new gammarid species in the eastern Gulf of Finland (Baltic Sea) and their effects on littoral communities. Proc Estonian Acad Sci Biol Ecol 52: 284-304.

Bij de Vaate A, Jażdżewski K, Ketelaars H, Gollasch S, Van der Velde G. 2002. Geographical patterns in range extension of macroinvertebrate Ponto-Caspian species in Europe. Can J Fish Aquat Sci 59: 1159-1174.

Boets P, Lock K, Messiaen M, Goethals PLM. 2010. Combining datadriven methods and lab studies to analyse the ecology of Dikerogammarus villosus. Ecol Inform 5: 133-139.

Borza P, Huber T, Leitner P, Remund N, Graf W. 2017a. Success factors and future prospects of Ponto-Caspian peracarid (Crustacea: Malacostraca) invasions: is 'the worst over'? Biol Invasions 19: $1517-1532$.

Borza P, Huber T, Leitner P, Remund N, Graf W. 2017b. Current velocity shapes co-existence patterns among invasive Dikerogammarus species. Freshw Biol 62: 317-328.

Borza P, Huber T, Leitner P, Remund N, Graf W. 2018. How to coexist with the 'killer shrimp' Dikerogammarus villosus? Lessons from other invasive Ponto-Caspian peracarids. Aquat Conserv Mar Freshw Ecosyst 28: 1441-1450.

Czarnecka M, Poznańska M, Kobak J, Wolnomiejski N. 2009. The role of solid waste materials as habitats for macroinvertebrates in a lowland dam reservoir. Hydrobiologia 635: 125-135.

Czarnecka M, Kobak J, Wiśniewski R. 2010. Preferences of juveniles and adults of the invasive Ponto-Caspian amphipod Pontogammarus robustoides for various species of macrophytes and artificial substrata. Hydrobiologia 655: 79-88.

Dermott R, Witt J, Um YM, González M. 1998. Distribution of the Ponto-Caspian amphipod Echinogammarus ischnus in the Great Lakes and replacement of native Gammarus fasciatus. J Great Lakes Res 24: 442-452.

DeVanna KM, Armenio PM, Barrett CA, Mayer CM. 2011. Invasive ecosystem engineers on soft sediment changethe habitat preferences of native mayflies and their availabilityto predators. Freshw Biol 56: 2448-2458
Devin S, Piscart C, Beisel JN, Moreteau JC. 2003. Ecological traits of the amphipod invader Dikerogammarus villosus on a mesohabitat scale. Arch fur Hydrobiol 158: 43-56.

Dick JTA, Platvoet D. 2000. Invading predatory crustacean Dikerogammarus villosus eliminates both native and exotic species. Proc Biol Sci 267: 977-83.

Dick JTA, Montgomery WI, Elwood RW. 1999. Intraguild predation may explain an amphipod replacement: evidence from laboratory populations. $J$ Zool 249: 463-468.

Dick JTA, Platvoet D, Kelly DW. 2002. Predatory impact of the freshwater invader Dikerogammarus villosus (Crustacea: Amphipoda). Can J Fish Aquat Sci 59: 1078-1084.

Dudgeon D, Arthington AH, Gessner MO, Kawabata ZI, Knowler DJ, Lévêque C, Naiman RJ, Prieur-Richard AH, Soto D, Stiassny MLJ, Sullivan CA. 2006. Freshwater biodiversity: importance, threats, status and conservation challenges. Biol Rev Camb Philos Soc 81: 163-182.

Effler SW, Brooks CM, Whitehead K, Wagner B, Doerr SM, Perkins M, Siegfried CA, Walrath L, Canale RP. 1996. Impactof zebra mussel invasion on river water quality. Water Environ Res 68: 205-214.

Everall NC, Johnson MF, Wood P, Farmer A, Wilby RL, Measham N. 2017. Comparability of macroinvertebrate biomonitoring indices of river health derived from semi-quantitative and quantitative methodologies. Ecol Indic 78: 437-448.

Gergs R, Rothhaupt KO. 2008. Effects of zebra mussels on a native amphipod and the invasive Dikerogammarus villosus: the influence of biodeposition and structural complexity. J North Am Benthol Soc 27: $541-548$.

Giziński A, Błędzki LA, Kentzer A, Wiśniewski R, Żytkowicz R. 1989. Hydrobiological characteristic of the lowland, rheolimnic Włoclawek Reservoir on the Vistula River. Ekol Pol 37: 359-403.

González MJ, Burkart GA. 2004. Effects of food type, habitat, and fish predation on the relative abundance of two amphipod species, Gammarus fasciatus and Echinogammarus ischnus. J Great Lakes Res 30: 100-113.

Gosselin LA, Chia FS. 1995. Distribution and dispersal of early juvenile snails: effectiveness of intertidal microhabitats as refuges and food sources. Mar Ecol Prog Ser 128: 213-223.

Grabowska J, Grabowski M. 2005. Diel-feeding activity in early summer of racer goby Neogobius gymnotrachelus (Gobiidae): a new invader in the Baltic basin. $J$ Appl Ichthyol 21: 282-286.

Grabowski M, Jażdżewski K, Konopacka A. 2007. Alien crustacea in polish waters - Amphipoda. Aquat Invasions 2: 25-38.

Gruszka P. 1999. The river Odra estuary as a gateway for alien species immigration to the Baltic Sea basin. Acta Hydrochim Hydrobiol 27: 374-382.

Hellmann C, Schöll F, Worischka S, Becker J, Winkelmann C. 2017. River-specific effects of the invasive amphipod Dikerogammarus villosus (Crustacea: Amphipoda) on benthic communities. Biol Invasions 19: 381-398.

Jażdżewski K, Konopacka A, Grabowski M. 2002. Four PontoCaspian and one American gammarid species (Crustacea, Amphipoda) recently invading Polish waters. Contribut Zool 71: $115-122$.

Jermacz Ł, Dzierżyńska A, Poznańska M, Kobak J. 2015a. Experimental evaluation of preferences of an invasive PontoCaspian gammarid Pontogammarus robustoides (Amphipoda, Gammaroidea) for mineral and plant substrata. Hydrobiologia 746: 209-221.

Jermacz Ł, Dzierzyńska A, Kakareko T, Poznańska M, Kobak J. 2015b. The art of choice: Predation risk changes interspecific 
competition between freshwater amphipods. Behav Ecol 26: 656-664.

Kakareko T, Żbikowski J. 2006. A tentative assessment of the influence of common bream Abramis brama (L.) on the prey populations and water chemistry in the Włocławek Reservoir in the lower Vistula. Limnol Papers 1: 25-38.

Kakareko T, Żbikowski J, Żytkowicz J. 2005. Diet partitioning in summer of two syntopic neogobiids from two different habitats of the lower Vistula River, Poland. J Appl Ichthyol 21: 292-295.

Karatayev AY, Burlakova LE, Padilla DK. 1997. The effects of Dreissena polymorpha (Pallas) invasion on aquatic communities in Eastern Europe. J Shellfish Res 16: 187-203.

Karatayev AY, Burlakova LE, Padilla DK. 2002. Impacts of zebra mussels on aquatic communities and their role as ecosystem engineers. In: Leppäkoski E, Gollasch S, Olenin S, Eds. Invasive Aquatic Species of Europe. Distribution, Impacts and Management. Dordrecht: Springer, pp. 433-446.

Kasprzak K. 1981. Skąposzczety wodne. Klucze do oznaczania bezkręgowców Polski (Aquatic oligochaetes. Identification keys for determination of invertebrates of Poland), PWN, Warszawa, 256 p. (in Polish)

Kley A, Maier G. 2003. Life history characteristics of the invasive freshwater gammarids Dikerogammarus villosus and Echinogammarus ischnus in the river Main and the Main-Donau canal. Arch fur Hydrobiol 156: 457-469.

Kley A, Maier G. 2005. An example of niche partitioning between Dikerogammarus villosus and other invasive and native gammarids: a field study. J Limnol 64: 85-88.

Kley A, Kinzler W, Schank Y, Mayer G, Waloszek D, Maier G. 2009. Influence of substrate preference and complexity on co-existence of two non-native gammarideans (Crustacea: Amphipoda). Aquatic Ecol 43: 1047-1059.

Kobak J, Żytkowicz J. 2007. Preferences of invasive Ponto-Caspian and native European gammarids for zebra mussel (Dreissena polymorpha, Bivalvia) shell habitat. Hydrobiologia 589: 43-54.

Kobak J, Kakareko T, Poznańska M, Żbikowski J. 2009. Preferences of the Ponto-Caspian amphipod Dikerogammarus haemobaphes for living zebra mussels. J Zool 279: 229-235.

Kobak J, Jermacz Ł, Dzierzyńska-Białończyk A. 2015. Substratum preferences of the invasive killer shrimp Dikerogammarus villosus. J Zool 297: 66-76.

Kobak J, Rachalewski M, Bącela-Spychalska K. 2016. Conquerors or exiles? Impact of interference competition among invasive PontoCaspian gammarideans on their dispersal rates. Biol Invasions 18: 1953-1965.

Kobak J, Jermacz, Rutkowska D, Pawłowska K, Witkowska L, Poznańska M. 2017. Impact of predators and competitors on the depth selection by two invasive gammarids. J Zool 301: 174-183.

Koester M, Gergs R. 2014. No evidence for intraguild predation of Dikerogammarus villosus (Sowinsky, 1894) at an invasion front in the Untere Lorze, Switzerland. Aquat Invasions 9: 489-497.

Koester M, Bayer B, Gergs R. 2016. Is Dikerogammarus villosus (Crustacea, Gammaridae) a "killer shrimp" in the River Rhine system? Hydrobiologia 768: 299-313.

Koester M, Schneider M, Hellmann C, Becker J, Winkelmann C, Gergs R. 2018. Is the invasive amphipod Dikerogammarus villosus the main factor structuring the benthic community across different types of water bodies in the River Rhine system? Limnologica 71: $44-50$.

Konopacka A. 2004. Inwazyjne skorupiaki obunogie (Crustacea, Amphipoda) w wodach Polski (Invasive amphipod crustaceans (Crustacea, Amphipoda) in Polish waters). Przeglad Zoologiczny 48: 141-162 (in Polish).
Krisp H, Maier G. 2005. Consumption of macroinvertebrates by invasive and native gammarids: a comparison. J Limnol 64: 55-59.

Leigh C, Bonada N, Boulton AJ, Hugueny B, Larned ST, Vander Vorste R, Datry T. 2016. Invertebrate assemblage responses and the dual roles of resistance and resilience to drying in intermittent rivers. Aquat Sci 78: 291-301.

Lucy F, Minchin D, Holmes JMC, Sullivan M. 2004. First records of the Ponto-Caspian amphipod Chelicorophium curvispinum (Sars, 1895) in Ireland. Irish Nat J 27: 461-464.

MacNeil C. 2019. Predatory impacts of the invasive "killer shrimp" Dikerogammarus villosus on a resident amphipod and isopod (Crustacea: Malacostraca) are influenced by water quality and habitat type. Hydrobiologia 833: 53-64.

MacNeil C, Dick JTA, Elwood RW. 1997. The trophic ecology of freshwater Gammarus spp. (Crustacea: Amphipoda): Problems and perspectives concerning the functional feeding group concept. Biol Rev 72: 349-364.

MacNeil C, Dick JTA, Elwood RW. 1999. The dynamics of predation on Gammarus spp. (Crustacea: Amphipoda). Biol Rev 74: 375-395.

MacNeil C, Platvoet D, Dick JTA. 2008. Potential roles for differential body size and microhabitat complexity in mediating biotic interactions within invasive freshwater amphipod assemblages. Fundam Appl Limnol 172: 175-182.

MacNeil C, Dick JTA, Platvoet D, Briffa M. 2011. Direct and indirect effects of species displacements: an invading freshwater amphipod can disrupt leaf-litter processing and shredder efficiency. $J$ North Am Benthol Soc 30: 38-48.

Maier G, Kley A, Schank Y, Maier M, Mayer G, Waloszek D. 2011. Density and temperature dependent feeding rates in an established and an alien freshwater gammarid fed on chironomid larvae. J Limnol 70: 123-128.

Muskó IB. 1993. The life history of Dikerogammarus haemobaphes (Eichw.) (Crustacea: Amphipoda) living on macrophytes in Lake Balaton (Hungary). Arch fur Hydrobiol 127: 227-238.

Muskó IB, Balogh C, Tóth ÁP, Varga É, Lakatos G. 2007. Differential response of invasive malacostracan species to lake level fluctuations. Hydrobiologia 590: 65-74.

Oksanen J, Blanchet FG, Friendly M, Kindt R, Legendre P, McGlinn D, Minchin PR, O’Hara RB, Simpson GL, Solymos P., Stevens MHH, Szoecs E, Wagner H. 2018. Vegan: Community ecology package. R package Version 2. 5-3. https://cran.r-project.org/web/ packages/vegan/vegan.pdf

Piechocki A, Wawrzyniak-Wydrowska B. 2016. Guide to freshwater and marine Mollusca of Poland, Bogucki Wydawnictwo Naukowe, Poznań, 280 p.

Piscart C, Bergerot B, Laffaille P, Marmonier P. 2010. Are amphipod invaders a threat to regional biodiversity? Biol Invasions 12: 853-863.

Piscart C, Roussel JM, Dick JTA, Grosbois G, Marmonier P. 2011. Effects of coexistence on habitat use and trophic ecology of interacting native and invasive amphipods. Freshw Biol 56: $325-334$.

Platvoet D, Dick JTA, MacNeil C, Van Riel MC, Van der Velde G. 2009. Invader-invader interactions in relation to environmental heterogeneity leads to zonation of two invasive amphipods, Dikerogammarus villosus (Sowinsky) and Gammarus tigrinus Sexton: Amphipod pilot species project (AMPIS) report 6. Biol Invasions 11: 2085-2093.

Poznańska M, Kobak J, Wolnomiejski N, Kakareko T. 2009. Shallow-water benthic macroinvertebrate community of the limnic part of a lowland Polish dam reservoir. Limnologica 39: 163-176.

Poznańska M, Kobak J, Wolnomiejski N, Kakareko T. 2010. Macrozoobenthos communities from two types of land-water 
transition zones in a European lowland dam reservoir. Fundam Appl Limnol / Arch fur Hydrobiol 176: 115-126.

Poznańska M, Kakareko T, Krzyżyński M, Kobak J. 2013. Effect of substratum drying on the survival and migrations of Ponto-Caspian and native gammarids (Crustacea: Amphipoda). Hydrobiologia 700: 47-59.

Poznańska-Kakareko M, Budka M, Żbikowski J, Czarnecka M, Kakareko T, Jermacz Ł, Kobak J. 2017. Survival and vertical distribution of macroinvertebrates during emersion of sandy substratum in outdoor mesocosms. Fundam Appl Limnol/Arch fur Hydrobiol 190: 29-47.

Rewicz T, Grabowski M, MacNeil C, Bącela-Spychalska K. 2014. The profile of a 'perfect' invader - the case of killer shrimp, Dikerogammarus villosus. Aquat Invasions 9: 267-288.

Ricciardi A, MacIsaac HJ. 2010. Impacts of biological invasions on freshwater ecosystems. In: Richardson DM, ed. Fifty Years of Invasion Ecology: The Legacy of Charles Elton. Hoboken, New Jersey: Wiley-Blackwell, pp. 211-224.

Richter L, Schwenkmezger L, Becker J, Winkelmann C, Hellmann C, Worischka S. 2018. The very hungry amphipod: the invasive Dikerogammarus villosus shows high consumption rates for two food sources and independent of predator cues. Biol Invasions 20: $1321-1335$.

Simberloff D. 2000. Nonindigenous species: a global threat to biodiversity and stability. In Raven P, Williams T, eds. Nature and Human Society: The Quest for a Sustainable World. Washington: National Academy Press, pp. 325-335.

Simberloff D, Von Holle B. 1999. Positive interactions of nonindigenous species: invasional meltdown. Biol Invasions 1:21-32.

Simberloff D, Martin JL, Genovesi P, Maris V, Wardle DA, Aronson J, Courchamp F, Galil B, García-Berthou E, Pascal M, Pyšek P, Sousa R, Tabacchi E, Vilà M. 2013. Impacts of biological invasions: What's what and the way forward. Trends Ecol Evol 28: 58-66.

Stewart TW, Miner JG, Lowe RL. 1998a. Quantifying mechanisms for zebra mussel effects on benthic macroinvertebrates: Organic matter production and shell-generated habitat. J North Am Benthol Soc 17: 81-94.

Stewart TW, Miner JG, Lowe RL. 1998b. Macroinvertebrate communities on hardsubstrates in Western Lake Erie: structuring effects of Dreissena. J Great Lakes Res 24: 868-879.

Stewart TW, Gafford JC, Miner JG, Lowe RL. 1999. Dreissena-shell habitat and antipredator behavior: combinedeffects on survivorship of snails co-occurring with molluscivorousfish. J North Am Benthol Soc 18: 274-283.

Timm T. 2009. A guide to the freshwater Oligochaeta and Polychaeta of Northern and Central Europe. Lauterbornia 66: 1-235.
Tubić B, Popović N, Raković M, Petrovic A, Simić V, Paunović M. 2017. Comparison of the effectiveness of kick and sweep hand net and Surber net sampling techniques used for collecting aquatic macroinvertebrate samples. Arch Biol Sci 69: 233-238.

Van den Brink FWB, Van der Velde G, Bij de Vaate A. 1993. Ecological aspects, explosive range extension and impact of a mass invader, Corophium curvispinum Sars, 1895 (Crustacea: Amphipoda), in the Lower Rhine (The Netherlands). Oecologia 93: 224-232.

Van Overdijk CDA, Grigorovich IA, Mabee T, Ray WJ, Ciborowski JJH, MacIsaac HJ. 2003. Microhabitat selection by the invasive amphipod Echinogammarus ischnus and native Gammarus fasciatus in laboratory experiments and in Lake Erie. Freshw Biol 48: $567-578$.

Van Riel MC, Van der Velde G, Rajagopal S, Marguillier S, Dehairs F, Bij de Vaate A. 2006. Trophic relationships in the Rhine food web during invasion and after establishment of the Ponto-Caspian invader Dikerogammarus villosus. Hydrobiologia 565: 39-58.

Van Riel MC, Healy EP, Van der Velde G, Bij de Vaate A. 2007. Interference competition among native and invader amphipods. Acta Oecol 31: 282-289.

Van Riel MC, Van der Velde G, Bij de Vaate A. 2009. Interference competition between alien invasive gammaridean species. Biol Invasions 11: 2119-2132.

Vander Vorste R, Malard F, Datry T. 2016. Is drift the primary process promoting the resilience of river invertebrate communities? A manipulative field experiment in an intermittent alluvial river. Freshw Biol 61: 1276-1292.

Wawrzyniak-Wydrowska B, Gruszka P. 2005. Population dynamics of alien gammarid species in the River Odra estuary. Hydrobiologia 539: $13-25$.

Wiederholm T. 1983. Chironomidae of the Holarctic region. Keys and diagnoses. Part. 1. Larvae. Entomologica Scandinavica Supplement 19, Lund, $457 \mathrm{p}$.

Wolnomiejski N. 1970. The effects of Dreissena polymorpha Pall. aggregation on the differentiation of the benthonicmacrofauna. Acta Universitatis Nicolai Copernici, Limnological Papers 5: 31-39.

Żytkowicz J, Kobak J. 2008. Relationships between the occurrence of Chaetogammarus ischnus (Stebbing, 1898) and Pontogammarus robustoides (G. O. Sars, 1894) (Crustacea, Amphipoda) in a lowland Polish dam reservoir. Oceanol Hydrobiol Stud 37: 39-50.

Żytkowicz J, Kobak J, Kakareko T, Kentzer A. 2008. Species composition and distribution of invasive Ponto-Caspian amphipods in the off-channel microhabitats of a temperate, lowland dam reservoir. Int Rev Hydrobiol 93: 62-72.

Cite this article as: Poznańska-Kakareko M, Lis M, Kakareko T, Augustyniak M, Kłosiński P, Kobak J. 2021. Near-shore distribution of alien Ponto-Caspian amphipods in a European dam reservoir in relation to substratum type and occurrence of macroinvertebrate taxa. Knowl. Manag. Aquat. Ecosyst., 422, 5. 